\title{
Public Policy in the Development of Export Crops: Pineapples and Tea in Kenya
}

\author{
Nicola Swainson
}

Recent World Bank reports (and the work of Robert Bates) have placed the blame for Africa's current economic crisis squarely in the lap of the African governments. They argue that the inadequate representation of farmers within the development coalition has given rise to the bleeding of agriculture to support industrial development. According to them, Africa's current economic crisis is due to excessive levels of state intervention and domestic mismanagement. These views have given rise to recommendations for 'structural reforms', the gist of which is that reduced state intervention and freeing up of markets will promote greater incentives for farmers and general economic 'efficiency'.

In this paper I intend to explore the general issue of state and market in agricultural development through an examination of Kenyan experience, focusing on a case study of two commodities whose development has taken different paths in the post-colonial period. I shall be concerned, first, to investigate the determinants of specific policy decisions on these two export crops. It is my contention that policy choice does not merely reflect considerations of technical or economic efficiency, but is deeply embedded in the political and social context. Discussion of policy choices will therefore be situated in the context of the wide range of conditions and constraints (national and international; economic, ecological and political) which have staged the development of these two commodities. Historically, this article concentrates on the specific conjuncture of factors which give rise to a particular policy outcome, such as the choice of the estate form of production in the case of pineapples in the 1960s. Second, particular attention is paid to examining the nature and type of state intervention over time, the specific mixture of public and private involvement in the development of each commodity, in terms of investment, marketing, scale and form of production and choice of technique.

\section{The State in Kenya}

It is important first to understand the origins and character of the Kenyan state which emerged in the post-colonial period. From the outset of colonial rule in Kenya, the administration represented both internal and external class forces, although the balance between these shifted in each historical period. In the inter-war years the resident section of estate capital, the white settlers, were the dominant political force. A highly interventionist form of state emerged with organisations such as crop marketing boards which facilitated the extraction of surplus from agriculture. African peasants were confined to 'Native Reserves' and hedged in by restrictions. The settlers controlled access to lucrative export crops like tea and coffee and African production was seen as 'complementary' to the European sector.

The balance of internal and external classes was torn apart by the rise of African nationalism in the postwar period. After World War II the ownership and control of capital began to undergo a shift in favour of international capital and settler economic and political power began to decline. New forms of finance capital became intimately linked with the interventionist state in Britain which was strongly influenced by Fabian socialism [Cowen: 1983]. The new colonial policy after World War II was fuelled by the need to raise levels of production and productivity in the territories. In Kenya the metropolitan state helped to facilitate the political transition from settler monopoly power to African majority rule. Economically, it broke the settler monopoly in agriculture and began to encourage peasant smallholder schemes. Both of the case studies here were designated crops under the Swynnerton Plan of 1954 which sought to develop African smallholder agriculture [Swainson: 1980, ch 3].

With the advent of independence in 1963 an embryonic African bourgeoisie took over the formal reins of power and this group dominated the state politically. The post-colonial state in Kenya has been characterised by a dynamic fusion of national and international tendencies. For instance, there has been 
an extension of indigenous control over both agricultural production and trade at the same time as an increase in foreign investment and aid from abroad. The latter has become partly significant in the recessionary conditions of the early 1980s. It is against this historical and structural backdrop that we should view specific public policies to stimulate export crop production. Let us begin with pineapples.

\section{Pineapples}

Pineapples had been grown for the local market since the early colonial period. The development of pineapples for export was a feature of the post-war period when the colonial government wanted to encourage the flow of agricultural produce from sterling areas in order to ease the dollar deficit. The growing side of the industry formed part of the Swynnerton Plan and the colonial administration provided generous concessions to build up infrastructure to service a new canning factory in Thika, about 20 miles north of Nairobi. Kenya Canners was jointly owned by settler farmers and a British firm, Pickering and West. This company and a few smaller ones made up the East African Food Packers Association. The immediate problem facing the enterprise was to integrate smallholder inputs with factory production. The main issue concerning the industry was to maintain a consistent quality and flow of fruit into the factory. By 1957, in the face of falling international prices for canned fruit, the Canning Crops Board was set up by the colonial government to regulate the industry: to fix acreages through licensing and to guarantee the growers minimum prices.

The nature of international competition shaped the fortunes of this industry in Kenya. International prices for canned pineapple began to recover after 1960, at a time when the smallholder fruit was coming on stream. The factory needed to expand its processing capacity, but the British firm found that it lacked capital and expertise to expand operations effectively.

It was in this context that the large American conglomerate, the California Packing Corporation (Calpak or Delmonte), was given the managing agency for the Kenyan enterprise in 1964. In that year the Development Finance Corporation of Kenya (DFCK) made the company a loan for expansion conditional upon a technical link-up with the International Canning Organisation, dominated by Calpak [Kaplinsky 1979:826]. The whole expansion programme of the Kenyan company came to depend on the technical expertise and international market linkages that were offered by the large multinational. A new agreement was signed in 1965 which gave the company the option to take up a majority shareholding in the project.
In terms of organisation of pineapple production it was assumed that the company would develop its own estates at the same time as using the pineapples grown by African smallholders. The government proceeded to buy up large tracts of land in the Thika district which had been used for growing sisal and coffee. These estates were then leased by the company at a peppercorn rent (since it is not permitted in Kenya for foreign firms to purchase land directly). Nevertheless, the company continued to expect the Canning Crops Board to guarantee a throughput of smallholder pineapples to the factory until their own estates reached maturity. Indeed, between 1965 and 1968 the government encouraged further extensions in smallholder pineapples.

By 1968, it had become blatantly clear that the company preferred to phase out the smallholders and convert their production entirely. Kenya Canners complained that there was not a sufficient throughput of smallholder pineapples and the fruit did not meet the required standard for processing. Although it was never made explicit, the government helped the company to convert its production to the estate form on very favourable terms. Through their control of licensing, the Canning Crops Board was able to give Kenya Canners almost exclusive growing rights for canning pineapple in Kenya. By the late 1960s, therefore, many small farmers in the Thika district found they had no market for their produce since the company was rejecting their pineapples. Most of the African farmers were able to switch to other crops, although many were saddled with loans and the government was required to write off most of these debts [for further details see Swainson 1980:156-67].

Thus in a period of four to five years this large corporation had managed to gain control over the production and marketing of pineapples for export, and effectively strangle a smallholder growing scheme.

The company has established itself in Kenya in order to diversify from its traditional growing areas in the Philippines and Hawaii where labour unions had become demanding. Production costs in Kenya were lower and labour more subdued. Through a network of high level political alliances, the firm was able to enlist government assistance for its moves. Several government ministers were given shares and put on the board of directors. Using techniques appropriate to large-scale scientific production (such as mulching and use of fertiliser) and mechanisation, the firm was able to raise productivity and standards of the fruit. Naturally enough the labour force expanded rapidly, from 400 workers in 1961 (factory only) to over 10,000 by 1976 (factories and combined estate). The firm invested heavily in new equipment and machinery for both factory and estate operations and declared 
operating losses between 1965 and 1974. Admittedly the firm was ploughing back surplus from its operations into this massive expansion programme. However, Kaplinsky [1979] has calculated that the company managed to maximise its profit repatriation by under-invoicing exports and over-valuing intrafirm imports.

What were the factors behind the decline of the smallholder pineapple scheme and why did the industry in Kenya succumb to the 'logic' of large-scale production? First of all, the international market for canned pineapple (and fruit generally) is highly competitive and dominated by several large transnationals, including Calpak. With a highly competitive market the transnational firms in the fruit industry are faced with a constant struggle to improve productivity and maintain their edge. The central requirements of successful export production are to ensure homogeneity and quality. Mechanisation is a process suited to a product that requires a high level of homogeneity. Secondly, pineapples suitable for canning require very specific production conditions: they can only be grown at a particular altitude as the acidity level and size of fruit must be exactly right. The Thika district in Kenya is one of the few which fulfils all these ecological requirements. Third, the Canning Crops Board did not deliver in quality control and technical inputs effectively to African peasants in the 1950s. It may have been that there was not sufficient technical expertise channelled into the growing scheme at the crucial time, as was the case with tea. At a purely economic level pineapples for canning are grown most efficiently on large-scale estates, which is why this form is predominant in the global industry. Fourth, the political costs of this shift were kept within bounds. The destruction of a smallholder growing scheme in any other area of Kenya might have caused severe political problems. Although a number of Africans living on the edge of the estate 'zone' in Thika were inconvenienced by the loss of their market, they responded by switching to other crops. Despite the fact that there was considerable political opposition to this turn of events, there was no major threat of social unrest [Swainson 1980:163]. Many people in the area were subsequently drawn into wage labour on the estates or in the factory.

The colonial state played a major role in developing the pineapple industry in the 1950s in Kenya by providing organisation for the growers and subsidised infrastructure for the factory. The post-colonial state in the 1960s assumed responsibility for the smallholder growing scheme. The form of production required by the international market and lack of existing organisational networks compelled the government to restructure the industry by collaborating with a major transnational firm. By means of high level political alliances the firm was able to extract extensive concessions from the government which enabled it to establish a monopoly position in the production of pineapples for export.

\section{The Case of Tea}

Tea was first planted in Kenya in the early 1920s and it has played a central role as an export earner from the 1930 s to the present. Before World War II, tea along with coffee was grown exclusively on settler or foreign owned estates. There has been a rapid expansion in tea production in post-colonial Kenya, with production rising from 138,000 metric tons in 1960 to 966,000 metric tons in 1980 (KTDA Annual Reports). Most of this increase can be explained by. raised productivity on the estates and the expansion of the smallholder tea area. Tea grown by African peasants has accounted for roughly one third of total annual marketed tea output by volume and more than one third by value since the mid 1970s. In the year $1980 / 81,85$ per cent of smallholder tea was exported [Lamb and Muller 1982:1].

Since the 1920s tea in Kenya has been dominated by several large corporations, notably Brooke Bond (now Brooke Bond Leibig) which had extensive interests in India and Sri Lanka. Tea was established as a plantation crop for export much earlier than pineapple. The two major firms, Brooke Bond and James Finlay, were able to purchase large areas of land from settlers in the west of Kenya. This area around Kericho was ideal for tea cultivation, being at the correct altitude with good rainfall and on the edge of an impoverished reserve area (Nyanza) which supplied cheap labour for the estates. After World War II, in the face of intensified world market competition, it was necessary for the large firms to raise productivity. The Brooke Bond company applied scientific methods, and better forms of labour organisation and unions were recognised on the tea estates.

\section{(i) The smallholder tea scheme}

Tea along with pineapples was promoted as a 'designated crop' to be grown by African farmers under the Swynnerton Plan. This scheme gave individual land tenure to Africans in certain areas of the country and broke the racial barrier surrounding major export crops such as tea. The board responsible for coordinating the smallholder tea scheme in Kenya was the Special Crops Development Authority (SCDA) which became the Kenya Tea Development Authority (KTDA) after independence in 1963. The KTDA has in the contemporary period been hailed as one of the most successful examples of institutional development in contemporary Africa. The scheme is 
considered a model of smallholder rural development and the KTDA an 'efficient' public sector enterprise.

The SCDA in the 1950s was composed of government staff and experts from the commercial tea companies, Brooke Bond, James Finlay and Eastern Produce. The success of the tea scheme lay in the sequenced control of strategic aspects of the tea cycle and control of the quality of both production stock (i.e. tea plants) and the growers. The cultivation of tea was controlled through a tight system of licensing. In the 1950s sundried tea (locally grown by Africans and sold in informal markets) was declared illegal in order to develop and maintain high standards of cultivation on peasant plots. Government nurseries supplied the African farmers with tea plants, and by the 1970s they were able to use vegetative propagation methods on their own plots to obtain new plants.

The foreign companies were initially hostile to the smallholder tea scheme as they feared falling prices and loss of market control. Nevertheless, they soon realised that this scheme could be used to their own advantage so long as standards were enforced and the product could be integrated into their global system. The firms in the 1950s provided their expertise to the Department of Agriculture on both the growing and manufacturing side of tea production. They assisted in the construction of KTDA factories during the 1960s and 1970s and provided management for the authority until local managers could be trained. The latter objective was achieved by the late 1960 s. By 1981 , out of the 27 KTDA factories, only eight were managed under contract by three foreign firms.

The authority has tried to restrict the average size of holding to one hectare in order to ensure quality, and strict plucking standards (two leaves and a bud) have been adhered to in most areas. Plucking standards are more difficult to supervise on estates. Appendix 1 shows that the rate of increase in yields per hectare for estates was much higher than for smallholder tea between 1971 and 1982. However, it must be borne in mind that the level of inputs into estate production is much higher than that for smallholders. Smallholder tea in Kenya is of a consistently higher quality than that grown on estates. The advantage to the Brooke Bond Corporation is that they can buy the higher quality teas from the KTDA and blend these with lower quality tea that was cheaper to produce.

\section{(ii) Finance for the smallholder scheme}

During the colonial period, the tea scheme represented a project of international capital, while in the postcolonial era it came increasingly under local control [Cowen 1983]. After independence the KTDA became more autonomous, and independent from commercial companies such as Brooke Bond. The tea scheme was initially a project of the Colonial Development Corporation (CDC), an organisation of finance capital set up after World War II to promote industrial and agricultural projects in the colonial territories [for further details on the history of the CDC, see Rendell 1976]. The CDC has continued to play a central role in financing the scheme, although the World Bank financed much of the factory construction and infrastructural development in the 1970s and 1980s. The CDC had lent approximately $£ 16 \mathrm{mn}$ st. to the KTDA by 1981 , and it continued to be involved in the factory construction programme.

Other external funding has been provided by the West German government, the European Investment Bank and OPEC. The Kenya government and parastatal financial corporations have also provided substantial loan capital to the KTDA [Lamb 1982:15]. In 1973 there were 17 factories, but by 1984 the number had grown to 33. The cost of servicing loans ( 75 per cent of which are designated in foreign currency) became a big burden on the KTDA in the 1981/82 recession. The tea scheme has consistently relied upon international finance to build up infrastructure and productive facilities.

\section{(iii) Payment system}

Much of the current discussion of the efficacy of agricultural policy in Africa has centred on payment and incentives for farmers. The tea growers in Kenya are remunerated by a complex incentive system which takes the form of first and second payments. The first payment is made by weight of green leaf and the second is made at the end of the year when factory production figures are clear. Fertilisers and other inputs are paid for by a deduction from the green leaf payment at the factory.

Though there is no comprehensive evidence of effects of tea development on smallholder incomes, estimates would suggest that most smallholder family units derive a comfortable income from tea. The average/annual grower income from tea in 1981 was K.Sh. 2,673, and for most households tea is not the only source of income [Lamb 1982:23]. Payments to growers are affected by the international price of tea which is reflected in their second payment. The KTDA have been relatively successful in keeping farmers consistently in tea, which is important due to the investment involved and the length of time required for tea plants to reach maturity. Pricing policy is crucial, otherwise growers will switch to other more profitable commodities such as dairy. Many of the senior managers of the KTDA have private tea growing interests but this does not seem to have affected the operational integrity of the authority [for further analysis see Swainson 1980:262-63]. 
The KTDA is now concentrating on consolidation rather than any further expansion of the area under cultivation. Due to the fact that Kenya produces relatively high quality teas, it would probably benefit from an international tea agreement limiting new planting and production [Schluter 1984:28].

\section{(iv) Reasons for the success of smallholder tea in Kenya}

Although not without its problems, the KTDA's record has been very good by comparison with other tea schemes, such as those in Tanzania and South Asia. Any comparison of smallholder schemes in particular countries must take into consideration different historical conditions. Lamb has suggested that the institutional features of the KTDA itself have played an important role in the success of peasant tea. These institutional factors involve an efficient management structure which has been largely localised with a diminished foreign involvement. Operational and technical autonomy of the KTDA has been maintained and the authority has a high degree of centralised control over the conditions of production and distribution. Favourable incentive schemes were developed by the authority and payment to growers was always prompt.

Market conditions have been favourable for tea since the 1960s. The Corporation sells most of its tea on the Mombasa or London auctions, although some of the higher quality teas are sold directly under their factory label to European countries. The authority controls the internal distribution of tea, and 10 per cent of each factory's production (including the estates) is taken as a 'pool' for the internal market. The KTDA subsidises the cost of tea to the local consumer. The government does not levy onerous taxes on tea which would have reduced the proceeds to the peasant.

Grower participation has been another positive aspect of the tea scheme in Kenya. The KTDA has since the 1960 s encouraged farmers to participate in both policy making and implementation. The elected divisional and district tea committees, the provincial tea boards, and farmer representation on the KTDA board itself have provided formal channels for advising on the land allocation process, transmitting KTDA policy and forwarding grievances.

Originally the KTDA staff dominated at all levels, but the growers have increasingly taken the initiative and would appear to make a strong input into policy [Lamb 1982:19].

Another effective means of ensuring grower participation has been to encourage them to take shares in KTDA factories: in 198210 per cent of growers held shares in 16 tea factories. Lamb has stressed that these shareholders tend to comprise the richer stratum of tea farmers.

\section{A Comparison of Tea and Pineapple}

Clearly tea and pineapple production have taken very different routes. While tea production has increasingly shifted from estate to smallholder cultivation, precisely the opposite occurred in the pineapple industry where the Calpak conglomerate replaced smallholder production with large scale 'factory farming'. How do we account for this?

Part of the explanation lies in the origins of each of the schemes. The Swynnerton Plan of 1954 had been conceived and implemented by a metropolitan government intent upon breaking the dominance of estate capital (the settlers primarily) over export commodities. The tea scheme was singled out for particular nurturing by the CDC - motivated in part by the large potential for export revenues - and there was from the outset a massive moral and financial commitment to its success. No such funds were available for pineapple growing and that scheme was seen as being complementary to private capital, which managed the processing side of the operation.

The combined control over growing and processing in the case of tea contributed to the foundation of a well-integrated scheme. Despite nationalist demands in the mid 1960s for the pineapple industry to be taken over by the state, the independent Kenya government encouraged Calpak to develop estates by the provision of infrastructure and land. Quality control was undoubtedly more difficult in the case of pineapples than in the case of tea, hence the notable lack of success of the Canning Crops Board in ensuring a consistent product.

Labour processes tend to be restructured in response to changing social and political as well as economic circumstances. For example, in the case of tea despite the logic of 'economies of scale', both the colonial and the independent government after 1963 were prepared to invest heavily in small-scale production. Political considerations were foremost in the minds of colonial bureaucrats. More than half of smallholder tea in Kenya is located in the Central Province, an overcrowded reserve area which spawned the nationalist revolt against the British. The development of successful smallholder agricultural schemes in this area was seen as a way of developing a compliant and stable middle peasantry. Peasant production in the Central Province was also the bedrock of the Kenyatta regime in the post-colonial era. Nor is the World Bank blind to this kind of logic in their widespread support for peasant agricultural schemes. Forms of land- 
holding are regionally specific in Kenya. Large-scale pineapple cultivation was possible only by developing areas which had previously been planted with coffee and sisal. Displacement of peasant produce in this case did not cause more than a few political ripples.

The World Bank and others have tended to juxtapose 'public' and 'private' development routes as alternative policy options facing 'rational' planners. The preceding cases show clearly the way in which, from the colonial to post-colonial eras, economic development has involved the intertwining of public and private as well as local and foreign. What is clear is that the very 'success' of either industry in whatever historical stage was dependent on extensive state support. International finance, acting through the state, ensured the excellent infrastructure of the tea scheme in Kenya. A carefully established organisation and ready availability of funds ensured the development of a highly effective institutional structure which has proved to be enduring. No such favourable conditions existed in the case of pineapples from the 1950s which might have ensured the more effective integration of public and private forms of production. The fact that there was no incorporation of dominant indigenous farmers into the pineapple smallholder scheme as there was in tea was another factor militating against its success. Instead, the postcolonial government complied with the aims of a dominant transnational in order to convert the pineapple growing scheme into large-scale estates.

My previous work on the development of corporate capitalism in Kenya outlined the central role of the state in the colonial period in providing the preconditions necessary for successful capital accumulation in both agriculture and industry. If one bears in mind the historical background of commodity production in Africa it is hard to believe that removing state intervention and encouraging the 'free market' will solve economic problems in the long term. 'States and markets' are not mutually exclusive policy options but part of a wider process of capitalist development, which is subject to fluctuations and crises. 
APPENDIX 1

Tea production, area sown, yields, and smaller payments, 1971-82

\begin{tabular}{|c|c|c|c|c|c|c|c|}
\hline Year & Smallholders & $\begin{array}{l}\text { Product } \\
\text { Estates }\end{array}$ & Total & & Smallholders & $\begin{array}{l}\text { Area Sown } \\
\text { Estates }\end{array}$ & Total \\
\hline & \multicolumn{3}{|c|}{ (million kilograms) } & \multicolumn{4}{|c|}{ (1,000 hectares) } \\
\hline 1971 & 8.1 & 28.2 & 36.3 & & 20.5 & 22.8 & 43.3 \\
\hline 1972 & 13.1 & 40.2 & 53.3 & & 26.5 & 23.3 & 49.8 \\
\hline 1973 & 15.1 & 41.5 & 56.6 & & 31.2 & 23.6 & 54.8 \\
\hline 1974 & 16.2 & 37.3 & 53.5 & & 34.6 & 24.1 & 58.7 \\
\hline 1975 & 17.9 & 38.8 & 56.7 & & 37.2 & 24.3 & 61.5 \\
\hline 1976 & 21.5 & 40.5 & 62.0 & & 41.4 & 24.5 & 65.9 \\
\hline 1977 & 30.7 & 55.6 & 86.3 & & 43.6 & 24.9 & 68.5 \\
\hline 1978 & 34.8 & 58.6 & 93.4 & & 46.9 & 25.2 & 72.1 \\
\hline 1979 & 37.6 & 61.6 & 99.2 & & 48.9 & 25.4 & 74.3 \\
\hline 1980 & 34.0 & 55.9 & 89.9 & & 50.7 & 25.9 & 76.6 \\
\hline 1981 & 35.8 & 55.1 & 90.9 & & 52.7 & 26.2 & 78.9 \\
\hline \multirow[t]{2}{*}{1982} & 39.9 & 56.1 & 96.0 & & 54.7 & 26.4 & 81.1 \\
\hline & \multicolumn{3}{|c|}{ Yields of Mature Tea ${ }^{1}$} & \multicolumn{4}{|c|}{ Average Payment to Smallholders ${ }^{2}$} \\
\hline \multirow[t]{2}{*}{ Year } & Smallholders & Estates & National & First & Second & Total & $\begin{array}{l}\text { Total in } \\
1969 \text { Prices }\end{array}$ \\
\hline & \multicolumn{3}{|c|}{ (kilograms/hectare) } & \multicolumn{4}{|c|}{ (KSh/kilogram of green leaf) } \\
\hline 1971 & 874 & 1,356 & 1,207 & 0.88 & 0.55 & 1.43 & 1.32 \\
\hline 1972 & 1,071 & 1,885 & 1,588 & 0.88 & 0.99 & 1.87 & 1.59 \\
\hline 1973 & 1,027 & 1,900 & 1,542 & 0.88 & 0.33 & 1.21 & 0.91 \\
\hline 1974 & 905 & 1,673 & 1,328 & 0.88 & 0.52 & 1.40 & 0.90 \\
\hline 1975 & 873 & 1,699 & 1,309 & 0.88 & 0.72 & 1.60 & 0.90 \\
\hline 1976 & 811 & 1,741 & 1,245 & 0.88 & 2.54 & 3.42 & 1.74 \\
\hline 1977 & 985 & 2,352 & 1,575 & 1.00 & 1.38 & 2.38 & 1.08 \\
\hline 1978 & 1,004 & 2,433 & 1,591 & 1.00 & 1.33 & 2.33 & 0.96 \\
\hline 1979 & 1,011 & 2,531 & 1,613 & 1.00 & 1.75 & 2.75 & 1.02 \\
\hline 1980 & 821 & 2,278 & 1,364 & 1.00 & 1.50 & 2.50 & 0.82 \\
\hline 1981 & 821 & 2,217 & 1,327 & 1.00 & 1.51 & 2.51 & 0.73 \\
\hline 1982 & 851 & 2,230 & 1,331 & n.a. & n.a. & n.a. & n.a. \\
\hline
\end{tabular}

Sources: Data provided by the Kenya Tea Board: Kenya Tea Development Authority (KTDA). Annual Report and Statement of Accounts, 1980/81 (Nairobi): KTDA, 1981: KTDA Annual Report and Statement of Accounts, 1981/82(Nairobi: KTDA, 1982): and Kenya, Ministry of Economic Planning and Development, Central Bureau of Statistics, Economic Survey: 1979-82 (Nairobi: Government Printer, 1979-82).

1 Yields per hectare are estimated by dividing production by the total area sown with tea four years before to allow for time taken for the tea bush to mature after planting.

2 Average payments to smallholders are given for fiscal years, so the 1971 figures are for 1971/72 and so forth.

${ }^{3}$ Constant prices are estimated by averaging the upper, middle, and lower income groups under 'Nairobi Annual Retail Price Increases, 1970-82', in Economic Survey, 1979-82.

Quoted in Lamb and Muller 1982 
APPENDIX 2

Kenya's exports of selected horticultural crops, 1976-80

\begin{tabular}{lrrrrr}
\hline Crop & 1976 & 1977 & 1978 & 1979 & 1980 \\
\hline Quantity & & \multicolumn{5}{c}{ (metric tons) } \\
$\quad$ Tinned pineapple & 29.906 & 45,329 & 42,082 & 41.048 & 38.452 \\
Fresh vegetables & 11,835 & 12,919 & 12.599 & 14.400 & 14.859 \\
Tinned fruit and vegetable juices & 1,277 & 2.388 & 2.641 & 2.525 & 4.475 \\
Fresh tropical fruit & 2.287 & 4.909 & 5.260 & 4.526 & 5.083 \\
Dehydrated vegetables & 1.362 & 1.326 & 950 & 1.340 & 1.044 \\
& & & & & \\
Value & & & & & \\
Tinned pineapple & 139.6 & 210.3 & 191.7 & 186.3 & 177.1 \\
Fresh vegetables & 47.3 & 57.0 & 67.8 & 65.3 & 96.6 \\
Tinned fruit and vegetable juices & 7.3 & 10.7 & 12.2 & 20.0 & 38.1 \\
Fresh tropical fruit & 6.2 & 15.1 & 19.0 & 18.5 & 26.7 \\
Dehydrated vegetables & 15.3 & 17.7 & 18.8 & 23.8 & 18.3 \\
Total & 215.7 & 310.8 & 309.5 & 313.9 & 356.8 \\
\end{tabular}

Source: Kenya, Ministry of Finance, Statistical Branch, Customs and Excise Department. Annual Trade Report, 1976-80 (Nairobi: Government Printer, 1976-80).

Note: The percentages these crops have in the exports of all horticultural crops are 76.4 for $1976,76.6$ for $1977,85.6$ for 1978, 78.1 for 1979 and 75.2 for 1980 .

Quoted in Schluter 1984

\section{References}

Banaji, J., 1977, 'Modes of production in a materialist conception of history', Capiral and Class 3, August

Bates, R., 1984, Markets and States in Tropical Africa; the Political Basis of Agriculiural Policies, University of Catifornia Press, Berkeley

Cowen, M., 1983. 'The British state, state enterprise and an indigenous bourgeoisie in Kenya after 1945., Central London Polytechnic (mimeo)

Kaplinsky, R., 1979, 'Export-oriented growth: a large international firm in a small developing country', World Developmeni, vol 7

Kenya Tea Development Authority, (various years) Annual Reports, Nairobi
Lamb, G. and L. Muller, 1982, 'Cont rol, account ability and incentives in a successful development institution', Wor/d Bank Sraff Working papers, No. 550, Washington DC

Mueller, S., 1981, 'Barriers to the further development of capitalism in Tanzania: the case of tobacco', Capiral and Class, Autumn

Rendell, Sir W., 1976, The History of the CDC. Heinemann Educational Books, London

Schluter, M., 1984, Constraints on Kenya's Food and Beverage Exports, Report No. 44, International Food Policy Research Institute, Washington $\mathrm{DC}$

Swainson, N., 1980, The Development of Corporate Capiralism in Kenya, 19/8-1977, University of California Press and Heinemann Educational Books, Berkeley and London

World Bank, 1981, Accelerated Developmen in sub-Saharan Afica, Washington $\mathrm{DC}$ 